\title{
MEMAHAMI ISLAM SECARA UTUH DAN IMPLIKASINYA DALAM DUNIA PEN- DIDIKAN; KAJIAN PENDEKATAN FENOMENOLOGIS ANNEMARIE SCHIMMEL
}

\begin{abstract}
:
Oleh: Islam is an religion that is not only on the social and theological doctrine, but also Junaidi has an glorious civilization. Because of that, the number of experts who study about Hasanah Islam produce various definition. That matter also create variant interpretation and understanding. One thing that must be noticed is when religious radicalism grow and Email: negative stigma to Islam. In the same aspect, ideology doctrine of religious radicalism joens_07@yahoo.com hasanahthahir2@gmail.com having in sight in Indonesia, in other words in the educational institution which the main target is students. Annemarie Schimmel uses fenomenological approach to understand about Islam holistically and disclaim negative stigma about Islam. This

Universitas Ibrahimy approach also create natural thought of an religion based on the religion believer perspective. So the impact can minimize religious radicalism doctrine.

Keywords: Understanding Islam, Education, Fenomenological Approach.
\end{abstract}

\section{PENDAHULUAN}

Beberapa arsitektur Islam yang begitu indah dan tetap kokoh pada dewasa ini, merupakan sebuah bukti peradaban yang menandakan bahwa Islam telah memberikan etos kerja yang baik kepada para penganutnya. Alquran dan hadits sebagai dua sumber yang menjadi dasar agama Islam tidak hanya melahirkan doktrin-doktrin teologis dan doktrin sosial, akan tetapi juga melahirkan peradaban yang dapat diambil sebagai pelajaran pada saat ini. Peradaban-peradaban Islam pada saat itu bukan hanya berwujud arsitektur yang indah, melainkan pemikiran-pemikiran yang telah menjadi tradisi dalam pengembangan pengetahuan di era setelahnya.

Pada puncak keemasan Islam, para cendekiawan muslim sangat aktif dalam mentransformasikan ilmu pengetahuan ke berbegai generasi muda lintas multi-sains. Sehingga pada zaman itu berbagai pengetahuan tumbuh menjadi sebuah peradaban Islam yang begitu cerah. Kesuksesan tersebut tentu tidak akan lepas dari dukungan positif pemerintah Islam kala itu. Sehingga banyak bangunan-bangunan sekolah, perguruan tinggi, dan library yang berkembang pesat sekaligus menjadi pusat sarana penempaan kaum intelektualis muslim. Peradaban Islam menjadi pusat perhatian setiap mata pada masa itu, sebab Islam mengalami banyak kemajuan di bidang kedokteran, matematika, astronomi, sains, dan filsafat yang menjadi mother of science yang kemudian melahirkan cabang-cabang ilmu pengetahuan.

Kemjuan peradaban Islam mengundang banyak ketertarikan orang Barat untuk menimba berbagai ilmu. Mereka berbondong-bondong menuju daerah Islam untuk menuntut ilmu sains dan sebagainya, tepat pada abad ke 13. Dari ilmu yang mereka peroleh di dunia Islam kemudian mereka pulang ke daerahnya masing-masing untuk mengembangkan ilmu di barat. Sehingga pada abad ke 19, dunia Barat mengalami peradaban yang maju dan Islam pada saat itu mengalami kemunduran. Namun orang-orang Barat tetap datang ke dunia Islam dengan membawa ilmu-ilmu sains dan teknologi yang dasarnya pernah mereka pelajari sebelumnya di dunia Islam. ${ }^{1}$

\footnotetext{
${ }^{1}$ M. Dawam Rahardjo, Kritik Nalar Islamisme dan Kebangkitan
} Islam (Jakarta: Freedom Institute, 2012), 27. 
Meskipun dunia Islam mengalami kemunduran dan Barat mengalami kemajuan, tetapi dunia Islam pada saat itu masih menyimpan khazanah peradaban. Hal ini menjadikan orang-orang Barat yang memiliki sains dan teknologi tertarik untuk mengembangkan keahliannya dalam meneliti dan mengenali kembali dunia Islam, sehingga lahirlah orang Barat yang ahli di bidang ketimuran yang disebut dengan orientalis.

Para orientalis banyak yang mendefinisikan Islam dan memaknai Islam secara mendalam. Hal ini membuat Islam kaya akan definisi. Tentu tidak lepas juga bahwa di dalam Islam terdapat doktrin-doktrin yang begitu masif dan perlu adanya pemahaman atau interpretasi secara mendalam akan hal tersebut. Berbicara Islam tentu tidak akan lepas dengan eksistensi negara Indonesia yang mayoritas masyarakatnya memeluk agama Islam.

Sebagai Negara yang berdikari, eksistensi negara Indonesia adalah sebuah negara yang di atasnya berdiri ribuah kaki dengan latar belakang suku, ras, bahasa, agama, dan budaya yang berbedabeda. Di sini dapat dipahami bahwa Indonesia merupakan bangsa yang majemuk, di dalamnya terdapat banyak kultur yang tumbuh dan berkembang. Kerap kali Indonesia juga disebut sebagai negara multikultural. Hal tersebut dapat dibuktikan dari situs sosio-kultural dan letak geografisnya yang begitu luas dan beragam. ${ }^{2}$ Tercatat bahwa total seluruh pulau yang dimiliki Indonesia sekitar 17.504 pulau yang di antaranya kurang lebih 11 ribu pulau telah dihuni oleh 359 suku dengan keragaman bahasa mencapai 726. Tidak hanya itu, pada saat KH. Abdurahman Wahid berkuasa, agama yang sah dijalankan bagi pemeluknya di Bumi Pertiwi ini terdapat 6 agama. Pasca panambahan agama Konghucu secara legal dan sah di antara 5 agama sebelumnya yakni, Islam, Budha, Hindu, Kristen, Katolik. Akan tetapi, dalam 6 agama tersebut terdapat banyak aliran yang menghiasi di dalamnya dan beberapa bentuk organisasi sosial. Di samping itu bermunculan berbagai aliran kepercayaan-kepercayaan hidup yang tumbuh subur di teritorial Indonesia. ${ }^{3}$

${ }^{2}$ M. Ainul Yaqin, Pendidikan Multikultural; Cross-Cultural Understanding untuk Demokrasi dan Keadilan (Yogyakarta: Pilar Media, 2005), 4.

${ }^{3}$ Husni Mubarok, "Memahami Kembali Arti Keragaman: Dimensi Eksistensial, Sosial dan Institusional",
Beragamnya agama, suku, ras dan bahasa menimbulkan problem-problem intoleransi yang harus segera diatasi. Hal ini diindikasikan karena adanya gerakan-gerakan radikalisme agama yang mulai tumbuh di Indonesia. Tentu membasmi gerakan radikal dan terorisme tidak semudah membalikkan telapak tangan atau bahkan mengucapkan bimsalabim abrakadabra. Karena hal ini bersangkutan pada ranah kognitif, yakni pemahaman. Karena bila diinterogasi motif melakukan aksi terorisme dan radikalisme tersebut, mayoritas dari meraka mengatakan bahwa itu semua dilakukan sebab berdasarkan perintah agama. ${ }^{4}$ Alih-alih mereka yang melalukan aksi radikal tersebut selalu mengklaim bahwa semua yang telah dilakukannya merupakan suatu hal yang benar dan terpuji.

\section{PEMBAHASAN}

\section{Riwayat Hidup Annemarie Schimmel}

Di salah satu kota kecil negara Jerman yang bernama Effurt, Schimmel dilahirkan. Tepatnya pada tahun 1922 Masehi. Ia menjalani jenjang pendidikannya di Jerman, sampai Ia menyandang status doktor di Universitas Berlin dan Marbung University. Kepiawaiannya dalam menguasai berbagai bahasa menghantarkannya memperoleh gelar professor di beberapa kampus, termasuk Ankara. London, Harvard, dan Bonn. Ia sangat mahir dalam sepuluh bahasa, di antaranya bahasa Farsi, Arab, Dari, Urdu dan Turki.

Bidang mistisme Islam merupakan keahlian Schimmel. Ia telah berhasil dalam mempublikasikan 80 buku ilmiah, memperoleh 26 penghargaan di berbagai universitas baik selama kuliah ataupun ketika ia telah mengajar. Di samping itu, Schimmel juga mempunyai 5 gelar kehormatan, sedangkan guru besarnya dalam bidang studi Islam diperolehnya di Universitas Marbung dan Universitas Boon.

HARMONI Jurnal Multikultural \& Multireligius, Vol. 9, No. 35, (Juli-September: 2010), 33.

${ }^{4}$ Indriyani Ma'rifah, "Rekonstruksi Pendidikan Agama Islam: Sebuah Upaya Membangun Kesadaran Multikultural untuk Mereduksi Terorisme dan Radikalisme Islam," Conference Proceedings Annual International Conference on Islamic Studies (AICIS) XII IAIN Sunan Ampel Surabaya 5-8 November 2012: 227-228. 
Schimmel juga mempunyai ketertarikan yang besar terhadap ilmu tasawuf. Tidak heran jika buku dan artikel-artikel yang ia tulis juga banyak diwarnai oleh pembahasan-pembahasan mengenai tasawuf. Schimmel juga aktif menjadi keanggotaan beberapa golongan akademis, beberapa di antaranya ialah The Association For The Association, Midote East Studies Association.

Annemarie Schimmel sempat memperoleh anugerah tokoh perdamaian dari German Book Traders pada tahun 1945, tepatnya bulan Oktober. Ia memperolehnya karena banyak mempublikasikan tulisan-tulisan ilmiah tentang Islam yang mengurai Islam dengan apa adanya. Sehinnga jasanya dapat menciptakan orang Barat dan orang Muslim saling pengertian satu sama lain. Anugerah yang diperolehnya ini juga menjadi suatu hal yang menantang bagi Schimmel. Sebab banyak tokohtokoh Jerman, kaum terpelajar, dan juga beberapa penerbit yang mengecamnya.

Selama ia hidup, tujuan kokohnya ialah untuk menciptakan pemahaman tentang Islam, mendiskusikan Islam berulang-ulang guna mengentaskan persepsi terhadap Islam yang acap kali disebut sebagai agama yang susah dipahami. Maka dari itu Schimmel sering disebut-sebut sebagai ilmuan Barat yang membawa jembatan untuk menghubungkan kerangka berpikir barat dan Islam.

Beberapa tulisan Rehma Baba, Syekh Abdul Latif Bhitai dan karangan sufi lain di Pakistan menjadi pemuas dahaganya tentang ilmu-ilmu tasawuf. Selain itu, Schimmel juga kerap mengkaji pemikiran Muhammad Iqbal dan beberapa tulisan sufistik Mansur Hallaj, Ghalib, dan orang-orang Persia. Ia juga tidak meninggalkan tulisan para orientalis Jerman dan buku-buku Turki guna menambah khazanah keilmuannya.

Beberapa karyanya yang telah lahir dari pemikiran-pemikiran yang cukup produktif dan diterjemahkan ke dalam beberapa bahasa terkemuka dibilang cukup banyak. Adapun karya-karya Annemarie Schimmel dalam bahasa Inggris ialah sebagai berikut.
1. I am Wind Your Are Fire,
2. The Life and Work of Rumi,
3. Look I This is Love,

4. Poems Of Rumi; Mystical Dimensions Of Islam,

5. Islamic Names,

6. An Introduction,

7. Islam; An Introduction,

8. Ibn Abbad Of Ronda: Letters On The Sufi Path;

9. My Soul is a Woman, The Feminine in Islam. Telah diterjemahkan ke dalam bahasa Indonesia dengan judul Jiwaku adalah wanita ; Aspek feminine dalam Spiritualitas Islam.

10. The Mystery Of Number;

11. Rahasia Wajab Suci Ilabi

Namun salah satu karyanya yang paling banyak digemari oleh kalangan-kalangan pelajar di Indonesia ialah Mengurai Ayat-Ayat Allah.

\section{Metode dan Pendekatan yang Digunakan Annemarie Schimmel}

\section{Metode Deskriptif Eksploratif}

Schimmel melakukan riset dengan mendeskripsikan nilai-nilai sebagaimana mestinya temuan yang telah diperoleh. Meskipun sebatas konteks global, Schimmel tetap menjelaskannya sedemikian rupa sehingga pesan-pesan penelitian dapat diterima dengan baik oleh masyarakat-masyarakat yang menelaahnya. Kaca mata metodologis yang dipakainya merupakan sebuah metode fenomenologis. Suatu pengembalian fenomena dari tempat asalnya yakni di mana seseorang melaksanakan kegiatannya dan di mana mereka menetapkan area-area mereka, dinamakan fenomenologi.

\section{Pendekatan-Pendekatan}

a. Etik-Legalistik

Hal ini bermula ketika Sayyidina Ali bin Abi Thalib meninggal dunia. Maka keberadaan madzhabmadzhab mulai tumbuh hingga terkenal di benak kita dengan sebutan Madzhab Maliki, Madzhab Hanafi, Madzhab Syafi'i dan Madzhab Hambali. Dalam proses prosedural ubudiyahnya, keempat madzhab ini kerap kali mempunyai perbedaanperbedaan yang terjadi. Akan tetapi pasti terdapat suatu similaritas yang mendasari semuanya. Sehingga para ulama menciptakan sebuah metode yang sistemik dan prosedural untuk menjaga kenaturalan yang bersumber dari sunah-sunah Nabi dan kesucian firman-firman Allah SW'T. 
Contoh sederhanya ialah ketika hendak menguraikan hadits atau riwayat perilaku sang Nabi Muhammad sebagai suatu susunan hadits, maka harus ada ketetapan syarat isnad, yakni jumlah dan mutu keperibadian perawi. Namun tetap tidak menutup kemungkinan dalam agama ketidak munculan masalah-masalah baik itu bersumber dari internal ataupun eksternal. Hal ini dapat dilihat dari munculnya golongan fundamentalisme dalam agama Islam. Kaum fundamentalis meluncurkan kecamannya terhadap kalangan umat internal ataupun eksternal berdasarkan sumber-sumber yang telah terverivikasi dari teks suci. ${ }^{5}$

\section{b. Teologis-Filosofis}

Pada ranah sains, penekanan terhadap kehidupan secara global melalui kekuatan nalar diwakili oleh pendekatan filosofis. Akan tetapi penekanan pada hal-hal yang berkaitan dengan problematika ketuhanan dan religiusitas diwakili oleh pendekatan teologis. Penjelasan wahyu menggunakan pendekatan nalar, pertama kali diusung oleh filosof muslim terkemukan yakni, Al-Kindi. Dari masa ke mamsa, para filosof yang mengargumentasikan melalui pendekatan secara nalar ternyata ditemukan suatu konklusi yang sepadan dengan wahyu itu sendiri. Al-kindi adalah filosof Muslim yang pertamatama merasakan kebutuhan untuk menjelaskan wahyu secara nalar. Cuman, para filosof sering bertolak belakang dengan kaum sufi yang usahanya dalam memahami agama melalui pendekatan sufistik. Kaum filosof menyebutnya sebagai bagian dari takhayyul, sebab pendekatan yang digunakan oleh kaum sufistik cenderung pada irasionalitas.

\section{c. Pendekatan Sufistik}

Jika para filosof menggunakan pendekatan nalar untuk memahami suatu hal tentang tuhan, maka kaum sufistik justru berbeda dengan para filosof. Mengapa demikian? Sebab kaum sufistik memiliki dua pendekatan yang telah melekat dalam dirinya untuk dijadikan alat menuju sebuah pemahaman tentang Rab. Dua pendekatan tersebut ialah pendekatan intuitif dan cinta kasih. Namun pada prosesnya antara pendekatan intuitif dan cinta kasih tidak saling bertolak belakang, hanya sewaktu-waktu

5 Annemarie Schimmel, Rahasia Wajah Suci Ilabi (Bandung: Mizan, 2009), 35. yang satu lebih powerful daripada yang lain dalam diri sorang sufi.

\section{Pendekatan Fenomenologis Perspektif Annemarie Schimmel}

Dari perspektif akar sejarahnya, pada tahun 1764 kata fenomenologis mulai dikemukakan oleh J. H. Lambert sebagai sebuah teori kebenaran. Kemudian setahun setelahnya, istilah fenomenologis dipakai pada cabang ilmu filsafat. Penjelasan mengenai istilah fenomenologis diurai secara eksplisit dalam buku yang ditulis oleh Immanuel Kant dan Hegel. Pada fase setelahnya, Edmurd Husserl mempromosikan istilah fenomenologi ini sebagai filsafat murni dan otonom. Pada pertengahan abad 19, kemudian Husserl merancang landasan filsafat fenomenologis yang lebih sistematis yang pada fase-fase sebelumnya pendekatan ini hanya dipakai pada pendekatan ilmu filsafat dan sosiologi. Dari usahanya tersebut, menghantarkan Husserl terkenal sebagai bapak fenomenologi modern walaupun juga cukup banyak pakar-pakar fenomelogi seperti Thomas Luckmann, Alferd Schutz, Peter L. Berger dan lain sebagainya.

Maka dari itu, pendekatan fenomenologis mempunyai definisi yang beragam karena banyak para ahli yang mendefinisikan pendekatan tersebut. Di antara pengertian fenomenologis yang diusung oleh beberapa ahli ialah sebagai berikut :

1. Fenomenologi ialah sebuah paradigma falsafi yang memposisikan kembali hakikat-hakikat pada tataran eksistensi. Mampu memahami manusia secara holistik kecuali berdasarkan pada aktivitas yang telah dilakukannya.

2. Fenomenologi adalah kajian tentang hakikat tanggapan manusia, hakikat kesadaran manusia, dan lain sebagainya.

3. Fenomenologi adalah upaya untuk mendeskripsikan eksperimen manusia secara natural tanpa mengkaji lebih lanjut bagaimana kondisi eksternal kejiwaannya dan sebab-akibat pendapat ilmuan tentangnya, sejarawan dan sosiolog.

4. Hegel menjelaskan bahwa fenomenologi merupakan sains yang mendeskripsikan tentang sesuatu yang telah dipahami seseorang tentang pengalaman dan kesadarannya. 
Uraian tentang definisi fenomenologis di atas, dapat ditarik konklusi bahwa pendekatan fenomenologis merupakan sebuah ilmu filsafat yang berupaya mengurai pemahaman tentang kesadaran, tanggapan dan hakikat kegiatan-kegiatan yang telah dilakukan oleh manusia melalui fenomena yang dapat diamati.

Annemarie Schimmel juga menyumbangkan definisi agama serta membangun definisi pendekatan fenomenologis untuk kajian agama. Agama yang menjadi fokus riset Schimmel ialah agama Islam. Jadi pengertian pendekatan fenomenologi yang ia kembangkan secara khusus ditujukan pada agama Islam. Penelitian yang menggunakan pendekatan fenomenologis dinilai cukup sulit dan sangat terstruktur sehingga hasilnya dapat melihat esensi agama secara akurat. Mengapa demikian, karena peneliti fenomenologis harus mendeskripsikan apa adanya ketika ia hendak mendefinisikan sebuah agama melalui pemahaman yang dimiliki oleh penganutnya. ${ }^{6}$ Sehingga dalam kegiatan peneltian ini, peneliti dominan tidak melihat adanya prakonsepsi sebelum ataupun setelahnya. Kegiatan yang sifatnya menilai atau men-judge nyaris tidak ditemukan dalam riset fenomenologis.

Lebih jauh, Shimmel juga berpendapat bahwa penelitian yang menggunakan fenomenologis merupakan penelitian yang sangat tepat dan berguna untuk mengkaji atau memahami sebuah agama. Sederhananya, penelitian fenomenologi yang diusung oleh Schimmel berupaya melihat esensi agama melalui kajian intensif atau telaah terhadap fenomenologinya terlebih dahulu. Kemudian setelahnya baru bisa memasuki lapisan-lapisan terdalam yang dapat menguak tentang pemahaman pemeluk agama tentang tuhannya. Dengan itu, pengalaman ruhaniah tertinggi akan dapat dicetuskan dengan mengamati objek yang terindra. Seperti wujud angin dapat diketahui dari gerakan rumput dan gerakan dedaunan.

Frederich Heiler merupakan seorang tokoh yang banyak berjasa bagi Schimmel, sebab pemikiranpemikiran kritis Annemarie Schimmel banyak terlahir dari telaah karya Heiler. Tokoh lainnya ialah Husyan An-Nuri, seorang tokoh mistisme dari Baghdad. Berkat membaca pemikiran-pemikiran

\footnotetext{
${ }^{6}$ Annemarie Schimmel, Rahasia Wajah Suci Ilahi (Bandung: Mizan, 2009), 78.
}

yang dituangkan oleh Nuri dalam beberapa karya monumentalnya, hingga mendorong Schimmel mencetuskan konsep model cicin konsentris yang dapat digunakan sebagai pisau analisi dalam melakukan penelitian agama melalui pendekatan fenomenologis. Adapun model cincin konsentris yang dirancang oleh Scimmel terbagi menjadi empat lapisan lingkaran sebagai berikut :

1. Bentuk lapisan terluar model cincin konsentris:
a. Objek yang suci, ruang suci, waktu suci, bilangan suci dan tindakan suci.
b. Kata-kata suci yang diucapkan dan kata suci yang tertulis dalam kitab suci.
c. Manusia suci dan umat suci.

2. Wujud lapisan kedua atau lapisan dalam yang pertama ini disebut dunia imajinasi agama :
a. Konsep Tuhan
b. Konsep penciptaan (kosmologi dan antropologi),
c. Konsep wahyu,
d. Konsep penebusan dosa,
e. Konsep hari akhir (eskatologi).

3. Wujud lapisan ketiga atau lapisan dalam yang kedua disebut sebagai dunia pengalaman agama. yakni apa yang terjadi jauh di alam jiwa, seperti penghormatan kepada kesucian Tuhan, rasa takut, iman, harapan dan kecintaan pada Tuhan.

4. Wujud lapisan keempat atau lapisan dalam yang ketiga disebut dunia agama yang objektif. Pusat dari ligkaran itu adalah realitas ilahi.

a. Tuhan sebagai Deus revelatus. Yaitu tuhan yang menghadapkan pada manusia sebagai dzat yang maha suci, maha benar, maha pengasih dan maha sempurna,

b. sebagai Deus ipse atau absconditus. yakni tuhan sebagai Dia sebagai kesatuan yang mutlak.

Dari empat lapisan di atas, menurut Schimmel, terdapat keterkaitan dan saling terkait. Dari bentuk fisik seperti ungkapan, pemikiran, perasaan yang akhirnya terkait dengan realitas ilahi. Meskipun realitas ilahi tidak akan pernah terungkap wujudnya secara sempurna. Karena itu ciptaan Tuhan akan berkaitan dengan Dzat Tuhan yang ada dengan sendirinya. 


\section{Kontribusi Annemarie Schimmel Sebagai Upaya Memahami Islam}

Pendekatan fenomenologis yang diusung oleh Annemarie Schimmel banyak menyadarkan orientalis Barat dalam melakukan penelitian ilmiah yang lebih mendalam. Sebab pendekatan-pendekatan yang dilakukan oleh kaum orientalis Barat hanya berkutat pada aspek luarnya saja. Artinya hasil penelitian yang dilakukan tidak sampai pada jantung dari pemahaman agama itu sendiri. Sebab metode yang dipakai oleh kaum orientalis Barat cenderung berpendekatan sosiologis, historis, antropologis dan serupanya. Menurut Schimmel pendekatanpendekatan semacam itu hanya mampu melihat warna baju terluarnya saja, namun tidak bisa menganalisis lebih dalam tentang pemahaman agama yang dimiliki oleh pemeluknya. Lebih-lebih akan sangat tidak komprehensif jika berusaha memahami Islam hanya melalui pendekatan historisitas. Tentu hal ini rentan melahirkan statmen-statmen negatif tentang agama Islam.

Pendekatan fenomenologis Annemarie Schimmel terlalu sensitif jika diintegrasikan dengan pra-konsepsi para islamolog Barat. Sebab upaya memahami Islam secara utuh bisa tercemar dari pemikiran-pemikiran awal mereka yang menganggap Islam sebagai agama bidsab Kristen, agama yang menjadi benalu bagi Kristen. Senada dengan hal tersebut, para islamolog Barat juga menilai Islam sebagai agama yang tidak manusiawi serta mengajarkan nilai-nilai primitif. Hal ini dapat kita jumpai dalam karya-karya tulis mereka yang telah terpublikasikan, terutama dalam novel yang berjudul Satanic Verses dan jurnal-jurnal ilmiah yang intensif membicarakan Islam.

Pendekatan historis-kritis seringkali melahirkan kesimpulan rasional tapi meresahkan dan tidak tepat. Dengan pendekatan sosiologisantropologis, bisa jadi akan melahirkan kesimpulan dan penilaian bahwa berhaji adalah tidak penting karena hanya menghambur-hamburkan uang dan berdiam digunung, lari-lari kecil dan semacamnya. Puasa itu tidak rasional, karena mau berlapar-lapar selama satu bulan puasa ramadhan. Kesimpulan yang salah semacam ini disebabkan keterbatasan metode ilmiah dan kecenderungan peneliti yang hanya melihat wujud lahiriahnya saja dengan tanpa masuk ke dalam ranah alam ruhaniah/batiniah muslim. Sehingga Schimmel melawan itu semua melalui pendekatan fenomenologis yang memahami Islam dari sudut pandang pemeluk agamanya. Karena itu, pendekatan fenomenologi menjadi signifikan, menyejukkan dan solutif dalam upaya memahami Islam sesuai sudut pandang pemeluknya.

Upaya Schimmel di atas telah berkontribusi besar dalam mengintegrasikan, mengawinkan dan mendamaikan pendekatan normativitas dan historisitas dalam studi Islam pada zaman kontemporer ini yang selama ini sangat bertolak belakang. Normativitas sangat tektualis, jumud dan skriptualis. Sementara historisitas mengenyampingkan sakralitas dan cenderung bebas serta liberal dalam menafsirkan agama. Karena itu, Schimmel dengan pendekatan ini menawarkan cara menafsirkan Islam atau ritual muslim sesuai pengakuan muslim itu sendiri, bukan hanya dari hasil pengamatan peneliti yang hanya mengamati aspek kulit luarnya saja. Karena Islam tidak hanya terdiri dari aspek eksoteris tapi juga esoteris. Biarkan orang Islam atau objek penelitiannya menceritakan sendiri tentang pengalamannya dalam mempraktikkan sebuah agama. Dan apa yang diungkapkan oleh mereka adalah sebuah kebenaran yang harus diterima.

Itulah beberapa kontribusi Schimmel dalam membela Islam dengan cara mengintegrasikan, mendamaikan, menjembatani, merukunkan dan mengawinkan.

\section{Mengajarkan Nilai-Nilai Kesucian Islam Perspektif Annemarie Schimmel kepada Peserta Didik}

Sebagai bangsa yang berdaulat, legalitas hukum formal dan birokrasi kepemerintahan di Indonesia harus dijalankan sebagaimana mestinya serta wajib ditaati oleh seluruh elemen bangsa. Namun setelah runtuhnya kekuasaan orde baru, terjadi banyak konflik yang bertebaran di Indonesia. Khususnya adalah kian banyaknya aksi terorisme dan radikalisme Islam. Hal ini dibuktikan dengan adanya ledakan bom yang kurang lebih hanya dalam kurun waktu satu dekade. Sebut saja bom buku yang terjadi di masjid Mapolres Cirebon, bom buku yang diperuntukkan ke sejumlah tokoh-tokoh berpengaruh, bom bunuh diri yang terjadi di GBIS 
(Gereja Bethel Injil Sepenuh) Solo. Tidak hanya itu, hal yang paling mencengangkan juga adalag ledakan bom yang terjadi di Bali, yakni bom Bali 1, bom Bali 2, bom Hotel JW Marriot 1, bom Hotel JW Marriot 2, bom Hotel Ritz Carlton, sampai bom kepada Kedutaan Besar Australia. ${ }^{7}$

Merebahnya kasus terorisme yang terjadi, mengindikasikan pada satu terma bahwa masyarakat Indonesia belum sepenuhnya memahami arti keberagaman sosial dan rasa saling hormatmenghormati atau sikap toleransi. Di antara satu kalangan bisa jadi sangat menginginkan ketiadaan pluralitas yang dimiliki Indonesia menjadi sebuah bentuk ketunggalan belaka atau keseragaman (uniformity), yang mana tentu sangat bertolak belakang sekali dengan akar historis bangsa Indonesia dengan berbagai keragaman yang mengitarinya. Hal ini perlu mendapat perhatian yang khusus dari seluruh lapisan masyrakat, terlebih pemerintah, sebab bila dibiarkan liar begitu saja, maka yang akan terjadi tidak hanya ancaman terhadap keamanan rakyat, akan tetapi stabilitas pemerintahan. Jika aksi terorisme ini sudah mengenai jantung sebuah negara, yakni tatanan birokrasi yang sah, maka konflik akut akan terjadi secara permanen.

Jika paradigma Annemarie Schimmel memahami Islam secara utuh diajarkan kepada peserta didik di sekolah-sekolah, tentu hal ini akan membendung gerakan-gerakan radikalisme agama yang begitu masif di Indonesia. Sebab generasi muda adalah ujung tombak yang dapat merubah bangsa menuju sesuatu yang lebih baik. Sedini mungkin peserta didik dikenalkan dengan pemahamanpemahaman agama yang santun, objektif, dan lahir dari interpretasi pemeluknya. Sehingga rasa toleransi terhadap antar agama dapat tercipta dengan baik di lembaga-lembaga pendidikan. Lebih-lebih pada lembaga pendidikan pesantren yang fokusnya memang menyebarkan nilai-nilai Islam serta nilai toleransi. ${ }^{8}$

\footnotetext{
${ }^{7}$ Indriyani Ma'rifah, "Rekonstruksi Pendidikan Agama Islam: Sebuah Upaya Membangun Kesadaran Multikultural untuk Mereduksi Terorisme dan Radikalisme Islam," Conference Proceedings Annual International Conference on Islamic Studies (AICIS) XII IAIN Sunan Ampel Surabaya 5-8 November 2012: 227.

${ }^{8}$ Moh. Nawafil dan Hafifuddin Nur, Pendidikan Indigenous Ala Pesantren untuk Memperkokoh Karakter Generasi
}

Cara memahami agama yang real dan kontekstual sangat perlu ditanamkan pada diri peserta didik. Pemahaman-pemahaman yang tidak hanya mengandalkan pra-konsepsi hitoris, kultural dan sosiologis, akan tetapi jauh dari itu ialah memahami agama sesuai pemahaman pemeluk agamanya, lebihlebih tentang kedekatan pemeluknya terhadap tuhannya. Tentu siswa bisa berpikir secara kritis dan tidak gampang meyakini sesuatu yang mereka dapat dari satu sumber tertentu tanpa menganilis secara langsung dari yang bersangkutan. Sehingga yang timbul adalah rasa toleransi, simpati, saling mengasihi, pikiran-pikiran yang jernih antar siswa yang berbeda agama, khususnya siswa yang memeluk agama Islam.

Mengapa hal itu harus diperhatikan secara serius? Karena pendidikan telah dijadikan lahan empuk untuk mencuci otak para generasi muda agar berpikir radikal dan ektrimis tentang agama. Azyumardi Azra mengatakan bahwa kelompokkelompok teroris dan kaum radikalis menjadikan anak-anak sekolah sebagai target khusus rekrutmen kelompok tersebut. Beliau juga mengatakan bahwa terdapat penelitian-penelitian yang membuktikan bahwa adanya upaya rekrutmen siswa ke sekolahsekolah yang kemudian mereka dicuci otak dengan mencekoki pemahaman-pemahaman radikal tertentu. ${ }^{9}$

Pemahaman-pemahaman yang melenceng tentang Islam mulai didengungkan di mana-mana. Sehingga timbullah persepsi-persepsi negatif tentang Islam. Nilai-nilai Islam yang sebenarnya diganggu sehingga rupa-rupanya Islam tampak sebagai agama teroris. Maka dari itulah, nilai-nilai Islam yang diusung oleh Annemarie Schimmel juga perlu diajarkan kepada peserta didik agar nilai-nilai Islam yang sebenarnya bisa tertancap begitu dalam di hati mereka. Berikut ini ialah penjabarannya :

Milenial”, Edupedia: Jurnal Studi Pendidikan dan Pedagogi Islam, Vol. 5, No. 1, (Juli: 2020), 18.

9 Andik Wahyun Muqoyyidin, "Membangun Kesadaran Inklusif-Multikultural untuk Deradikalisasi Pendidikan Islam", Jurnal Pendidikan Islam, Vol. 2, No. 1, (Juni: 2013), 133-134. 


\section{Aspek-Aspek Suci Alam dan Kebudayaan}

1. Sifat Benda Mati

a. Batu

Dari mitologi bahwa batu yang membentuk dasar kosmos, yakni batu yang berwarna hijau dan berada jauh di dalam bumi serta merupakan poros vertikal yang memancang seluruh alam semesta. Terdapat salah satu batu yang menarik dan menawan serta banyak yang menyukainya, yakni batu "Hajar Aswad" di Kota Makkah. Batu yang hitam dan semerbak wanginya, banyak orang yang berlombalomba mencium dan mengusap batu itu untuk memperoleh keberkahan. ${ }^{10}$

Batu dapat berfungsi juga untuk mengekspresikan kemurkaan Tuhan sebagaimana beberapa referensi Qurani yang "menganggap batu" orang-orang yang ingkar. (Al-Quran [105]: 4)

b. Gunung

Gunung merupakan sebuah keagungan tuhan sebagaimana ayat Al-Quran yang menyatakan bahwa "Gunung-gunung itu bersujud di hadapan Allah" (Al-Quran [22]: 18). Gunung juga berfungsi sebagai tempat pertemuan para wali dan juga sebagai makam para ulama-ulama kharismatik. ${ }^{11}$

\section{c. Debu}

Banyak kalangan beranggapan bahwa debudebu yang berada pada makam-makam para wali atau kekasih Allah adalah membawa berkah tersendiri. Puisi tentang debu yang disyairkan oleh Turki Fuzuli bahwa "Puisiku bukan batu rubi ataupun jamrud, puisiku adalah debu, namun debu karbala!". Debu juga berfungsi untuk mensucikan diri bila tiada air yang akan digunakan untuk bersesuci.

\section{d. Air}

Air adalah sumber kehidupan bagi segala sesuatu, sebagaimana ayat al-quran bahwa "Kami menghidupkan segala sesuatu dengan air." Air juga berfungsi sebagai elemen yang berguna untuk mensucikan makhluk secara lahiri, beberapa mitologi juga menyebutkan bahwa air berguna untuk

\footnotetext{
${ }^{10}$ Annemarie Schimmel, Rahasia Wajab Suci Ilabi (Bandung: Mizan, 2009), 78.

${ }^{11}$ Ibid, 37.
}

penyucian hati. Air yang kerap kali berada di dekat makam para wali banyak yang beranggapan dapat membawa keberkahan.

e. Cahaya

Cahaya adalah tanda-tanda keberadaan Allah sebagaimana firman-Nya yang berbunyi "Allah adalah cahaya langit dan bumi". Allah membawa manusia dari kegelapan menuju cahaya yang terang benderang sebagaimana firman-Nya bahwa "min az-zulumati ila an-nur". Kewajiban manusia adalah kembali kepada arah cahaya dan takdir masa depannya akan ditentukan oleh tingkat iluminasi (keterpancaran) yang ia capai selama hidup.

2. Tumbuhan dan Binatang

a. Pohon

Pohon kehidupan yang cabangnya adalah nama-nama Ilahiyah, berakar dalam presensi Ilahiyah, di sisi lain persaksian keimanan dapat dipandang sebagai satu pohon yang kulit luarnya dibentuk oleh negasi la, merupakan negativitas murni dan yang aliran getahnya melalui $h$, huruf terakhir dan esensial Allah.

tubuh adalah sebuah pohon, buabnya akal; kebohongan dan kelicikan adalah jerami dan onak duri

\section{b. Binatang: Lebah}

Lebah merupakan seekor binatang penuh inspirasi yang kemampuannya untuk membangun rumah menunjukkan pada kebijaksanaan Allah. Tradisi populer di Turki dan Indo-Pakistan abad pertengahan mengklaim bahwa madu menjadi manis hanya ketika lebah tetap mendengungkan shalawat sharifa, shalawat kepada nabi, ketika mengumpulkan sari tumbuhan tanpa rasa.

\section{Obyek-Obyek Buatan Manusia}

Dalam tradisi Alquran, Dawud muncul sebagai seorang ahli dalam pembuatan perisai/ baju perang (sebagaimana semua nabi diperintahkan dalam satu profesi praktis). Sebagaimana hadits yang berbunyi la fata illa Ali, la sayf illa dzu al-fiqar. Artinya bahwa tidak ada pemuda heroik sejati kecuali Ali dan tidak ada pedang kecuali dzul fiqar. 


\section{Ruang dan Waktu Suci}

\section{Ruang Suci}

Masjid, semua orang memahami bahwa di dalam masjid akan memiliki efek penenangan jiwa. Oleh karenanya bayak yang memahami bahwa ruangan yang ada pada dalam masjid akan sering digunakan untuk istikharah, yaitu melaksanakan shalat istikharah dua rakaat kemudian tidur di dalam masjid.

\section{Waktu Suci}

Bulan ramadhan adalah waktu paling suci dalam setahun, karena pada bulan ini wahyu pertama al-quran diturunkan. Pintu neraka ditutup dan pintu surga dibuka. Laylatul qadr, malam kekuasaan atau penentuan, adalah malam yang lebih baik dari seribu bulan, hal tersebut berada pada malam ganjil bulan tersebut mungkin berada pada malam ke 27. Bulan lain yang dimuliakan juga dalam umat islam adalah bulan rabiul awal sebagaimana bulan ini adalah bulan kelahiran sosok agung, yakni Nabi Muhammad SAW.

\section{Angka Suci}

5 (lima) adalah angka uni di dalam Islam, di mana angka ini sering digunakan. Salah satu contohnya merupakan nilai nomerik untuk huruf h, huruf terakhir dan esensial kata Allah. 5 (lima) juga muncul pada tingkat yang lebih praktis dalam keimanan dan ritual: ada lima rukun Islam (penegasan keimanan shalat wajib, zakat, puasa di bulan ramadhan, haji ke Mekkah). ${ }^{12}$

\section{Tindakan yang Suci}

\section{Via Purgativa (Jalan Pemurnian)}

Berisi berbagai jalan untuk menyucikan diri seseorang dalam usaha menjaga hal yang suci (Ilahiyah). Biasanya juga berkaitan dengan ritual aporopaik, seperti upacara untuk mengusir kegiatan yang berbahaya. Misalnya penggunaan drum selama gerhana untuk menakuti setan. Mendengungkan suara tembakan ketika anak laki-laki baru lahir untuk menjauhkan setan dan jin agar tidak iri. Penggunaan

\footnotetext{
${ }^{12}$ Abdullah, Taufiq dan M. Rusli Karim, Metodologi Penelitian Agama Sebuah Pengantar, (Yogyakarta: Tiara Wacana Yogya, 1990), 78.
}

jenis wewangian tertentu untuk menolak aura-aura jahat. ${ }^{13}$

2. Via Illuminatifa (kaca mata iman)

Garis batas antara keadaan duniawi yang disingkirkan dengan tindakan penyucian dan keadaan ritual adalah niyyah (niat). Terkenal dengan ungkapan Al-amalu bi An-Niyyah. Innallab la yandzuru ila suwarikum, wa la ila ajsamikum, walakin yandzuru ila qulubikum.

3. Via Unitiva (bersatu dengan Allah)

"Mereka, yang mabuk akibat dari gelas piala Allah

Tidak merasakan apapun dari anggur "tidaklah aku?"

Sepanjang waktu berjuang demi kesalehan dan shalat, menyembah berhala sekarang, dan sekarang minum anggur...."

Para pecinta Allah berada di luar keabadian tanpa awal dan keabadian tanpa akhir, ada tempat di mana tidak ada tempat, semua tenggelam dalam kekasih ilahiyah.

\section{Firman dan Kitab Suci}

1. Kalam tentang Allah dari Allah

"Bukankah Aku tuhanmu?" Manusia masa depan menjawab "Ya, kami mempersaksikannya." (AlQuran [7]: 172)

Kalam yang berasal dari Allah dan mengungkapkan diri-Nya merupakan inti dari agama Islam. Wahyu sejati senantiasa penuh dengan misteri, perlu adanya interpretasi baru secara terus menerus guna menemukan hakikat makna yang benar-benar terkandung dalam kalamullah. Sebab wahyu yang dipahami utuh bukan wahyu yang sebenarnya dari tuhan yang tak terbatas dan terukur.

\section{Kalam Allah}

Dalam shalat wajib perlu menyebut nama Allah sebab hal itu adalah suatu hal yang dapat mengingatkan kekuasaan Allah yang maha besar. Do'a (shalat) merupakan inti dari sebuah agama

\footnotetext{
${ }^{13}$ Annemarie Schimmel, Rahasia Wajah Suci Ilabi (Bandung: Mizan, 2009), 95.
} 
sebab doa yang disebutkan merupakan pengorbanan, pengorbanan kata, sebagaimana Rumi mengatakan:

\section{Ketika mereka mengucapkan takbir, mereka berjalan menjauh}

Dari dunia kita, seperti sebuah pengorbanan:

Makna takbir, sahabatku, adalab ini:

"Ya Allah kami hendak menjadi kurban-Mu"

3. Kitab Suci

Al-Quran awal yang ditulis pada kulit binatang sebagaimana yang dinayatakan dengan tepat oleh Martin Lings memiliki suatu 'kualitas ikonik' padanya. Ibn Abbas mengatakan bahwa alquran diturunkan ke baitul izzah dalam satu malam yang kemudian diturunkan ke bumi secara bertahap sesuai konteks dan kondisi.

Tanda-tanda turunnya wahyu kepada Rasulullah SAW ialah bunyi suara lonceng yang sangat keras, kedinginan dan di sisi lain dahi Rasulullah berkeringat. Berdasar dari Sayyidina Umar yang pernah melihat bahwa tampak wajah Nabi kemerahmerahan dan napasnya tidak beraturan.

\section{Individu dan Masyarakat}

1. Manusia

Manusia diberi anugerah pengetahuan oleh Allah melalui nabi Adam A.S. sebagaimana firman Allah yang berbunyi "Tidaklah Dia mengajarkan kepadanya nama-nama, sehingga memungkinkannya memerintah makhluk dan memahami fungsi namanama Tuhan juga." Manusia adalah tanda eksistensi Allah di muka bumi. Jika manusia merenungkan akan dirinya maka ia akan menemukan keindahan sifat-sifat Tuhanya yang tiada tara.

2. Masyarakat

Al-quran mendefinisikan masyarakat sebagai ummatan wasathan. Yakni masyarakat tengah sebagai sekelompok orang yang mengambil jalan tengah di antara titik ekstrem. Dalam masyarakat tentu terdapat perbedaan. Nah, perbedaan tersebut itulan yang harus diredam melalui penghayatan pada hadits Nabi SAW bahwa "Perbedaan pendapat dalam kaumku merupakan suatu rahmat Allah."

\section{SIMPULAN}

Annemarie Schimmel lahir di salah satu kota Jerman yang bernama Effurt pada tahun 1922 Masehi. Ia terkenal sebagai tokoh orientalis Barat yang banyak melahirkan karya-karya berkaitan dengan Islam. Perjalanan studinya dimulai dari tempat negara kelahirannya, sampai ia berada di bangku universitas. Namun beberapa gelar guru besar ia peroleh dari pelbagai negara di dunia. Sehingga pada akhirnya Annemarie Shimmel terkenal sebagai ilmuan Islam yang cara memahami agama Islam dengan menggunakan pendekatan fenomenologis. Melalui pendekatan inilah, Schimmel dapat memahami Islam secara utuh. Pendekatan fenomenologi memberikan kesempatan seluas-luasnya bagi muslim untuk menceritakan pengalamannya sendiri. Karena itu, pendekatan fenomenologi menjadi signifikan, menyejukkan dan solutif dalam upaya memahami Islam sesuai sudut pandang pemeluknya. Fenomenologi ialah sebuah paradigma falsafi yang memposisikan kembali hakikat-hakikat pada tataran eksistensi. Mampu memahami manusia secara holistik kecuali berdasarkan pada aktivitas yang telah dilakukannya. Jika paradigma Annemarie Schimmel memahami Islam secara utuh diajarkan kepada peserta didik di sekolah-sekolah, tentu hal ini akan membendung gerakan-gerakan radikalisme agama yang begitu masif di Indonesia.

\section{DAFTAR RUJUKAN}

Abdullah, Taufiq dan M. Rusli Karim. Metodologi Penelitian Agama Sebuab Pengantar. Yogyakarta: Tiara Wacana Yogya, 1990.

Indriyani Ma'rifah, "Rekonstruksi Pendidikan Agama Islam: Sebuah Upaya Membangun Kesadaran Multikultural untuk Mereduksi Terorisme dan Radikalisme Islam," Conference Proceedings Annual International Conference on Islamic Studies (AICIS) XII IAIN Sunan Ampel Surabaya 5-8 November 2012: 227-228.

Mubarok, Husni. "Memahami Kembali Arti Keragaman: Dimensi Eksistensial, Sosial dan Institusional", HARMONI Jurnal Multikultural \& Multireligius, Vol. 9, No. 35, (Juli-September 2010. 
Muqoyyidin, Andik Wahyun. "Membangun Kesadaran Inklusif-Multikultural untuk Deradikalisasi Pendidikan Islam", Jurnal Pendidikan Islam, Vol. 2, No. 1, (Juni: 2013).

Nawafil, Moh. dan Hafifuddin Nur, »Pendidikan Indigenous Ala Pesantren untuk Memperkokoh Karakter Generasi Milenial", Edupedia: Jurnal Studi Pendidikan dan Pedagogi Islam, Vol. 5, No. 1, (Juli: 2020).

Rahardjo, M. Dawam. Kritik Nalar Islamisme dan Kebangkitan Islam. Jakarta: Freedom Institute, 2012.

Schimmel, Annemarie. Rahasia Wajah Suci Ilahi. Bandung: Mizan, 2009.

Yaqin, M. Ainul. Pendidikan Multikultural; Cross-Cultural Understanding untuk. Demokrasi dan Keadilan. Yogyakarta: Pilar Media, 2005. 